\title{
MJFAS MALASIIA JOURNAL OF

\section{Physical and chemical properties of LSCF-CuO as potential cathode for intermediate temperature solid oxide fuel cell (IT-SOFC)}

\author{
Ahmad Fuzamy Mohd Abd Fatah, Noorashrina A. Hamid* \\ School of Chemical Engineering Universiti Sains Malaysia, Engineering Campus, Nibong Tebal, Pulau Pinang 14300 Malaysia
}

* Corresponding author: chrina@usm.my

\section{Article history}

Submitted 12 June 2018

Revised 27 June 2018

Accepted 16 July 2018

Published Online 3 September 2018

\begin{abstract}
Solid oxide fuel cells (SOFCs) are efficient yet environmentally benign devices that can convert chemical energy into electrical energy and heat for large scale of applications. However, higher operating temperature of this device limits the selection of proper materials to be used as electrode and electrolyte as well as sacrifices the durability. Thus, it is desirable to develop materials with superior electrochemical performance at intermediate temperature $\left(600-900{ }^{\circ} \mathrm{C}\right)$ for SOFC. $\mathrm{LaSrCoFeO}_{3}$ (LSCF) doped with $\mathrm{CuO}$ is an attracting yet promising cathode material for IT-SOFC owing to the distinguish properties including high electrical conductivity and high catalytic activity for the oxygen reduction reaction. This work investigates the influence of the synthesis route which are sloid state route and sol-gel route towards chemical and physical properties of composite LSCF$\mathrm{CuO}$. The samples were synthesized at different temperature ranging from $600^{\circ} \mathrm{C}$ to $900^{\circ} \mathrm{C}$ for each route respectively. XRD results showed high purity of as-synthesized samples while in the meantime increased in crystallinity has been observed as increased in calcining temperature indicating bigger crystal size after calcined at $900^{\circ} \mathrm{C}$. SEM images showed LSCF-CuO particles tends to expand as the calcining temperature increased. Meanwhile, from TGA results it is clear to conclude that LSCF$\mathrm{CuO}$ loss its weight significantly after calcined at designed temperature.
\end{abstract}

Keywords: Sol-gel, solid-state reaction, LSCF-CuO, characterization

(c) 2018 Penerbit UTM Press. All rights reserved

\section{INTRODUCTION}

Solid oxide fuel cells (SOFCs) operate on the basis of thermally activated electrochemical reaction which requires a relative high operating temperature (Singh et al., 2014). A typical SOFCs single cell consists of three basic components which are anode, cathode and electrolyte. Each of these components must fulfill a suitable specific requirement such as stability of microstructural, same thermal expansion, porosity, and catalytic activity (Minh \& Takahashi, 1995; Singhal 2000). One of the most important aspects on maintaining the high performance of SOFCs is the chemical compatibility of the components inside the cathode must be high to be able to withstand high operation temperature without reacting to each other.

In SOFCs, there is one factors that indicates that the performance of the cells which is the oxygen reduction reaction process. This process need a better chemical compatibility of the cathode and if it fails, then consequently lead the cells performance to be degrade (Simner et al., 2003; Petitjean et al., 2005). One step to improve the oxygen reduction reaction process is by applying mixed ionic electronic conducting (MIEC) material (Virkar et al., 2000). The uses of this approach is to increase the active area for the ORR process due to the fact that pure electronics conductors in this reaction was limited to the triple boundary phase(TBP) where electrolyte, electrode and gas phase. Then the ORR takes place and oxygen ion enter electrolyte material. Therefore, substantial ionic conductivity of the MIEC material opens the pathway for oxygen ion migration also through the MIEC itself and therefore spreads the possible reaction zone (Fleigh, 2002). LSCF consist of lanthanum, strontium, cobalt and ferrite. LSCF also widely used as a cathode due to the excellent ionic and electronic conductivities that capable on expanding the active sites from the triple boundary phase to the entire cathode surface (Singh \& Minh, 2005).
However, Simmer et al. mention that one of the flaw on using the LSCF as cathode is the addition of cobalt able to improve the conductivity but in the same time it form a high resistive materials with the cells electrolyte during the cathode sintering process at high temperature (above $1000^{\circ} \mathrm{C}$ ) than could degrade the performance of the cells (Simner et al., 2006). These points were explained by Kim et al. (2010) where a conventional sintering at a temperature above $1000^{\circ} \mathrm{C}$ cannot be used in metal supported SOFCs as the processing temperature is limited by oxidation of the metal substrate. Therefore, LSCF type cathode most likely suitable for application on intermediate temperature range. . Another way to improve MIEC material is by applying composite cathode method. This technique require additional noble metal that would act as a catalyst in the MIEC type cathode. MIEC type cathode such as LSCF could be used to be composite with noble metal such as $\mathrm{CuO}$. In order to increase the electro-catalytic activity as well as reducing the calcining temperature, addition of copper oxide $(\mathrm{CuO})$ has been done by Lu et al. (2012) toward the LSCF cathode. However, it still needs to be assessing in term of ratio and synthesizing route in order to optimize the performances. Generally, application of $\mathrm{CuO}$ composite toward various type of cathode has a capability to be a good catalyst for chemical reaction and effective sintering aid of ceramics as reported previously (Lu et al., 2012; Ran et al., 2006; Zhao et al., 2009; Reitz et al., 2000).

There are usually two popular ways to produce SOFC type cathode which are solid state route and sol-gel route. Solid state route involve the use of high operating condition which is high temperature in order to synthesize the cathode materials. It is important in order to ensure the cathode materials is pure from any contaminant and also to produce desired particle size powder depending on the requirement. This method introducing milling process in order to reduce the particle size of the materials so the possible air trapped inside the cathode can be 
reduce. The sol-gel route has more complex method compare to solid state route. Sol or solution is a combination of two phase which are liquid and solid phase which forming a gel type structure. It usually require a polymerization agent such as ethylene glycol and the chelating agent such as citric acid in order to perform the sol-gel route (Zhu et al., 2013). It converts monomers into sol-gel state that will act as a precursor for an integrated network. In common case or undergoing in sol-gel method, the density of the composition supposed to be low as most of the liquid will be exile from the composition in order to produce gel type structure. Thus, this paper reported about the effects of each method toward the chemical and physical properties of LSCF-CuO as potential cathode material for IT-SOFCs.

\section{EXPERIMENTAL}

\section{Materials}

The starting materials, Lanthanum nitrate hexahydrate (La $\left(\mathrm{NO}_{3}\right)_{3} .6 \mathrm{H}_{2} \mathrm{O}, \mathrm{CAS}, 10277-43-7 \quad \mathrm{MERCK}^{\circledR}$, 99\%), Strontium nitrate $\left(\mathrm{Sr}\left(\mathrm{NO}_{3}\right)_{2}\right.$, Grade AR, Friendemann Schimdt Chemical, 99\%), Cobalt nitrate-hexahydrate $\left(\mathrm{Co}\left(\mathrm{NO}_{3}\right)_{2} .6 \mathrm{H}_{2} \mathrm{O}\right.$, ChemAR $\left.{ }^{\circledR}, 99 \%\right)$, Ferum nitrate-nonahydrate $\left(\mathrm{Fe}\left(\mathrm{NO}_{3}\right)_{3} .9 \mathrm{H}_{2} \mathrm{O}, \mathrm{ChemPur}^{\circledR}, 99 \%\right)$, and Ethyl alcohol $\left(\mathrm{C}_{2} \mathrm{H}_{5} \mathrm{OH}\right.$, R\&M Chemicals, 95\% V/V denatured) were used as the precursor for solid state route while for while sol gel route require Lanthanum nitrate hexahydrate $\left(\mathrm{La}\left(\mathrm{NO}_{3}\right)_{3} .6 \mathrm{H}_{2} \mathrm{O}\right.$, CAS, 10277-437 MERCK $\left.^{\circledR}, 99 \%\right)$, Strontium nitrate $\left(\mathrm{Sr}\left(\mathrm{NO}_{3}\right)_{2}\right.$, Grade AR, Friendemann Schimdt Chemical, 99\%), Cobalt nitrate-hexahydrate (Co $\left(\mathrm{NO}_{3}\right)_{2} .6 \mathrm{H}_{2} \mathrm{O}, \quad$ ChemAR $\left.{ }^{\circledR}, 99 \%\right)$, Ferum nitrate-nonahydrate $(\mathrm{Fe}$ $\left(\mathrm{NO}_{3}\right)_{3} .9 \mathrm{H}_{2} \mathrm{O}$, ChemPur ${ }^{\circledR}$, 99\%), citric acid monohydrate $\left(\mathrm{C}_{6} \mathrm{H}_{8} \mathrm{O}_{7} . \mathrm{H}_{2} \mathrm{O}, \mathrm{R} \& \mathrm{M}\right.$ Chemicals, $\left.99 \%\right)$ and ethylene glycol $\left(\mathrm{C}_{2} \mathrm{H}_{6} \mathrm{O}_{2}\right.$, Grade A.R, R\&M Chemicals, 99\%).

\section{Synthesis of LSCF-CuO powder form and pellet form}

The $\mathrm{La}_{0.6} \mathrm{Sr}_{0.4} \mathrm{Co}_{0.2} \mathrm{Fe}_{0.8} \mathrm{O}_{3-}$ (LSCF) precursor powder was synthesized by conventional solid state method and sol-gel method. Solid state method following the conventional solid state method where all metal nitrate $\mathrm{La}\left(\mathrm{NO}_{3}\right)_{3}, \mathrm{Sr}\left(\mathrm{NO}_{3}\right)_{2}, \mathrm{CO}\left(\mathrm{NO}_{3}\right)_{2}$ and $\mathrm{Fe}\left(\mathrm{NO}_{3}\right)_{3}$ were mixed together and excess ethylene glycol was added into the mixture. The salt mixture was crushed using pestle and mortar for 30 minute and it was transferred into beaker. The mixture was heated at $100^{\circ} \mathrm{C}$ to remove excess nitrate for 6 hour. The resulted mixture was calcined for 6 hour at different temperatures which are $600,700,800$ and $900^{\circ} \mathrm{C}$ in air and the resulted sample was crushed using pestle and mortar. The copper oxide $(\mathrm{CuO})$ was prepared by calcining the copper nitrate at the same temperature for the LSCF sample. The sample for characterization was prepared by mixing the LSCF powder and $\mathrm{CuO}$ powder with weight ratio 1:1, followed by calcining for 6 hour in air. The final result was crushed again using pestle and mortar. The sol-gel method is following the polymerized complex method. All metal nitrates were dissolved in water with ratio $6: 4: 2: 8$. Then the metal nitrates mixture was mixed with ethylene glycol and citric acid with weight ratio 1:0.5:1. The ethylene glycol will act as a polymerization agent and the citric acid will act as chelating agent (Zhu et al., 2013). Then, the mixture was stirred for 3 hour at $100^{\circ} \mathrm{C}$. The resulted gel was charred at $320^{\circ} \mathrm{C}$ for 3 hour to remove the excess citric acid and then calcined at $600,700,800$ and $900^{\circ} \mathrm{C}$ for 6 hour. The resulted sample was crushed using pestle and mortar and copper oxide was added with weight ratio $1: 1$. The mixture was calcined again for 6 hour. Finally, the resulted sample was crushed again using pestle and mortar.

The pellet form of LSCF-CuO was prepared using with diameter $13 \mathrm{~mm}$ using iron die cast.

\section{Characterization of LSCF-CuO powder}

The phase composition was characterized by using X-ray diffraction (XRD) with $\mathrm{Cu} \mathrm{K} \alpha$ radiation from $10 \theta$ to $90 \theta$ for the entire sample by use an AXS Bruker GmbH. The raw data from the XRD analysis was analysed using Xpert-Highscore plus. The main sample of $\mathrm{LSCF}-\mathrm{CuO}$ at $800^{\circ} \mathrm{C}$ was compared with literature and from synthesized LSCF and $\mathrm{CuO}$ sample with same temperature. The thermal decomposition behaviour of the precursor powder was made using a TGA analyser model Pelkin Elmer STA 600, from room temperature to $900^{\circ} \mathrm{C}$ with air flowrate of $50 \mathrm{~cm}^{3} / \mathrm{min}$ and heating rate of $5^{\circ} \mathrm{C} / \mathrm{min}$ in air.

The microstructure of the LSCF-CuO powder was investigated using Scanning Electron Microscopy (SEM) using Quanta FEG 650. The acceleration voltage was $15-20 \mathrm{kV}$, using backscattering electron. The behaviour of the microstructure of the sample was defined at 500 $\mathrm{nm}$ and $5 \mu \mathrm{m}$. The Energy-Dispersive X-ray (EDX) was conducted on Quanta FEG 650 using behaviour of microstructure at $5 \mu \mathrm{m}$. The specific surface area and total pores volume of the LSCF-CuO was measured using Brunauer-Emmett-Teller (BET) with average mass 0.15 gram per sample.

\section{RESULTS AND DISCUSSION}

\section{Physical and chemical properties of LSCF-CuO}

The XRD analysis indicated that all the sample of LSCF-CuO powder were single phase when the temperature above $800^{\circ} \mathrm{C}$ since some unidentified peaks were found between $20^{\circ}$ to $30^{\circ}$ at temperature below $800^{\circ} \mathrm{C}$. The peak of LSCF showed that it was shifted toward the high-angle indicating that the inter-diffusion of La ions in LSCF. The data of LSCF-CuO from the XRD pattern was compared with LSCF and $\mathrm{CuO}$ data in Fig. 1. The temperature chosen for the comparison is at $800^{\circ} \mathrm{C}$. The entire peaks have been identified as LSCF and $\mathrm{CuO}$. In order to increase the precision of identified peak, the sample also being compared with the data from other literature(Lu et al., 2012) and it was found that all peak identical with the synthesized LSCF, $\mathrm{CuO}$ and identically method.
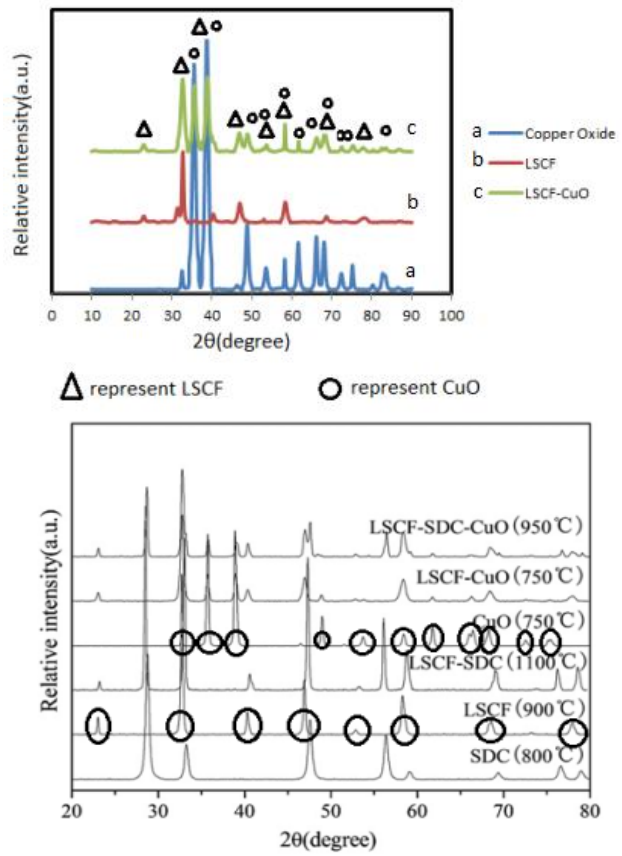

Fig. 1 XRD identified phase.

All sample were compared to each other and it was found that the optimal temperature for $\mathrm{LSCF}-\mathrm{CuO}$ processing via solid state route was $800^{\circ} \mathrm{C}$ and $600^{\circ} \mathrm{C}$ for sol gel processing since the LSCF-CuO were obtained as shown in Fig. 2 by respective route. Furthermore, the addition of $\mathrm{CuO}$ able to reduce the calcining temperature required for LSCF from $900^{\circ} \mathrm{C}$ to $800^{\circ} \mathrm{C}$ via solid state route and from $900^{\circ} \mathrm{C}$ to $600^{\circ} \mathrm{C}$ via sol-gel route since the optimal temperature for LSCF processing usually at $900^{\circ} \mathrm{C}$ and above. As for comparison for both routes, the sol-gel route shows lower temperature required for complete perovskite formation of LSCF-CuO in the cathode. It could be explained that the polymerization process in sol-gel help to improve the formation of perovskite as well as reducing the calcining temperature. This can be contributed as the catalysis of $\mathrm{CuO}$, which made the activation energy of the formation reaction of the LSCF to be reduced. $\mathrm{CuO}$ could act as a catalyst due to the synergistic catalytic activity of $\mathrm{CuO}$ on the LSCF surface for both routes. In recent work, the low 
coverage of $\mathrm{CuO}$ particle on the LSCF surface were able to enhance the ORR kinetics which resulting the LSCF-CuO performance better than LSCF or $\mathrm{CuO}$ type cathode (Hong et al., 2016). $\mathrm{CuO}$ also demonstrated a good chemical compatibility with LSCF since it was able to produce a single phase perovskite at the stated temperature. Thus, it indicates that LSCF-CuO composite could perform well in SEM and TGA analysis.
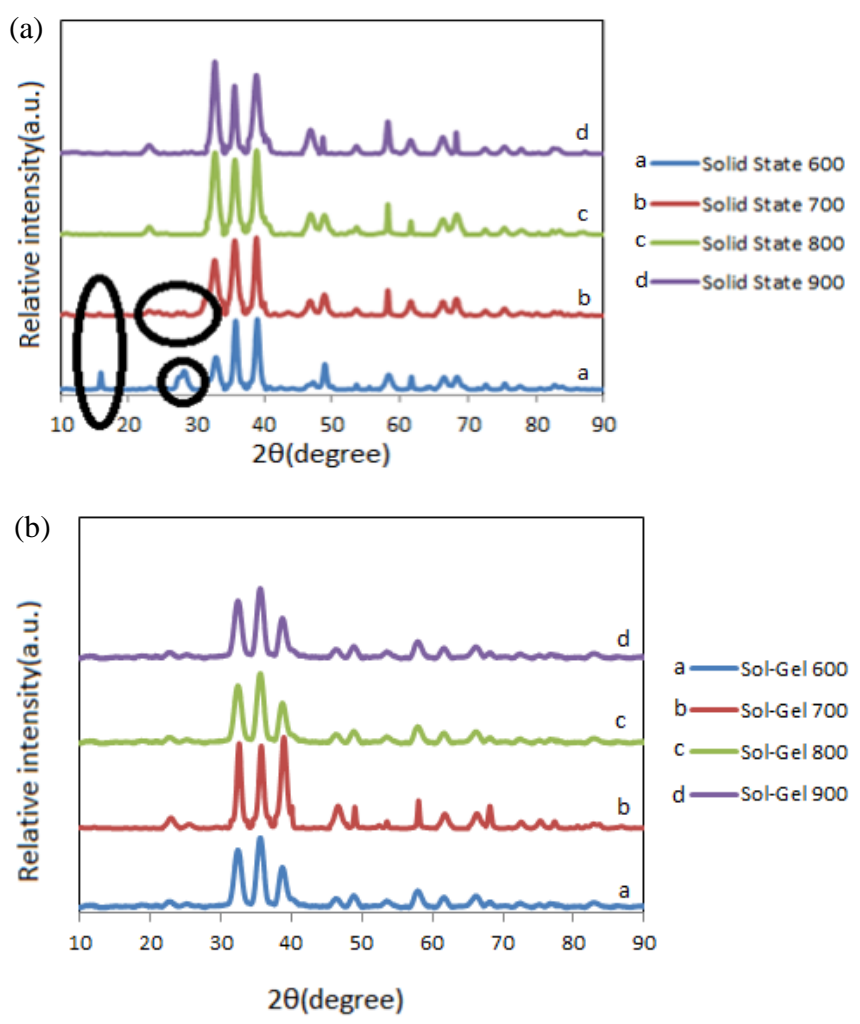

Fig. 2 XRD pattern sample on various temperatures (a) Solid state route and (b) Sol-gel route.

In order to verify the results from the XRD analysis, EDX analysis was conducted to identify the respecting element in the samples. EDX data represents the chemical properties for the sample. Fig. 3 showed that the EDX analysis for each respective temperatures and routes. It was found out that all sample in respective temperature were highly pure due to no impurities were found in that sample. Thus, this may showed that the additional peak on XRD data might be represent as unwanted solid state product which could be either $\mathrm{LaO}_{3}$ or $\mathrm{SrO}_{3}$ which still did not perform the single phase perovskite yet due to insufficient calcining temperature.

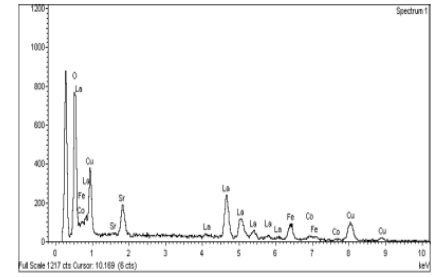

Temperature: $600^{\circ} \mathrm{C}$ Identify Element: La,Sr,Co,Fe,Cu,O

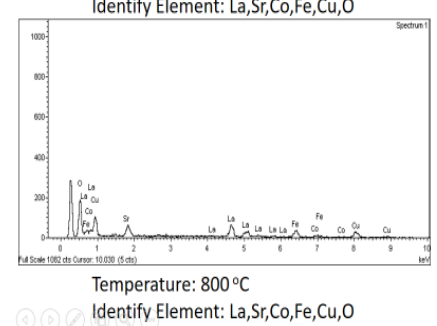

Identify Element: $\mathrm{La}, \mathrm{Sr}, \mathrm{Co}, \mathrm{Fe}, \mathrm{Cu}, \mathrm{O}$

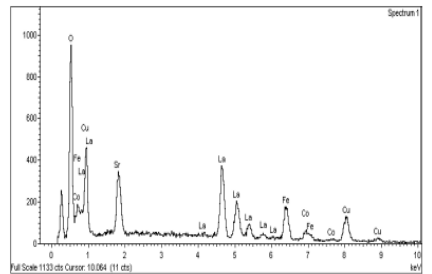

Temperature: $700^{\circ} \mathrm{C}$ Identify Element: $\mathrm{La}, \mathrm{Sr}, \mathrm{Co}, \mathrm{Fe}, \mathrm{Cu}, \mathrm{O}$

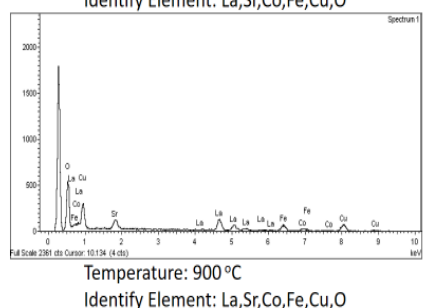

(a)

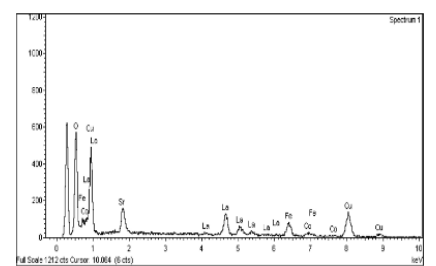

Temperature: $600^{\circ} \mathrm{C}$

Identify Element: $\mathrm{La}, \mathrm{Sr}, \mathrm{Co}, \mathrm{Fe}, \mathrm{Cu}, \mathrm{O}$
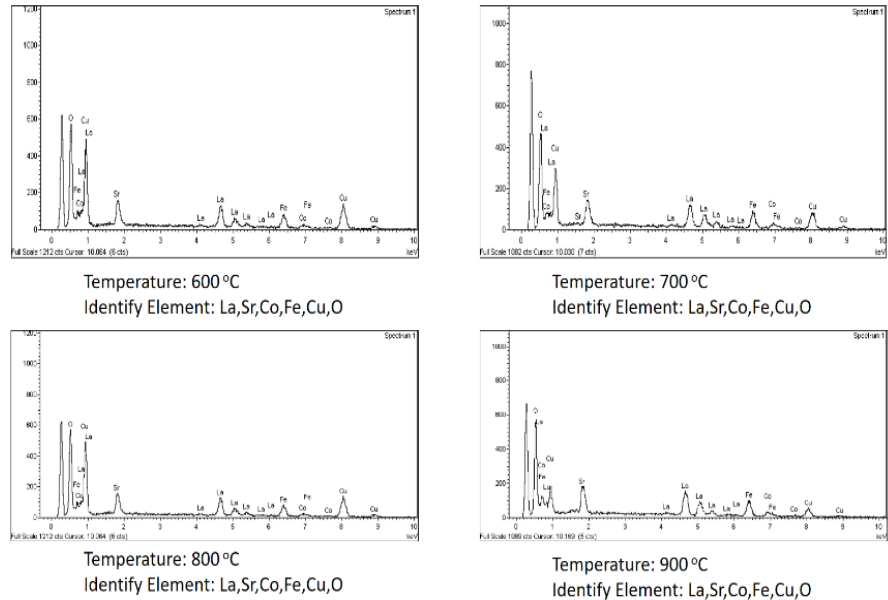

Temperature: $700^{\circ} \mathrm{C}$

Identify Element: $\mathrm{La}, \mathrm{Sr}, \mathrm{Co}, \mathrm{Fe}, \mathrm{Cu}, \mathrm{O}$

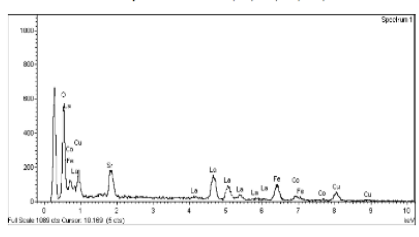

Temperature: $900^{\circ} \mathrm{C}$

Identify Element: $\mathrm{La}, \mathrm{Sr}, \mathrm{Co}, \mathrm{Fe}, \mathrm{Cu}, \mathrm{O}$

(b)

Fig. 3 EDX analysis on respective sample (a) Solid state route and (b) Sol-gel route.

Next, the samples for both route were undergoes the SEM analysis in order to investigate the microstructure of the cross-section of LSCF$\mathrm{CuO}$ composite cathode materials is shown in Fig. 4. All sample produce a very well porous interlayer and it also showed a rhombohedral type grain which is good definition of having a wellstructured porosity since rhombohedral structure form a sharp edge which resulted a gap between one to another. The fine grain and connection between them were well-connected to each other.

(a)
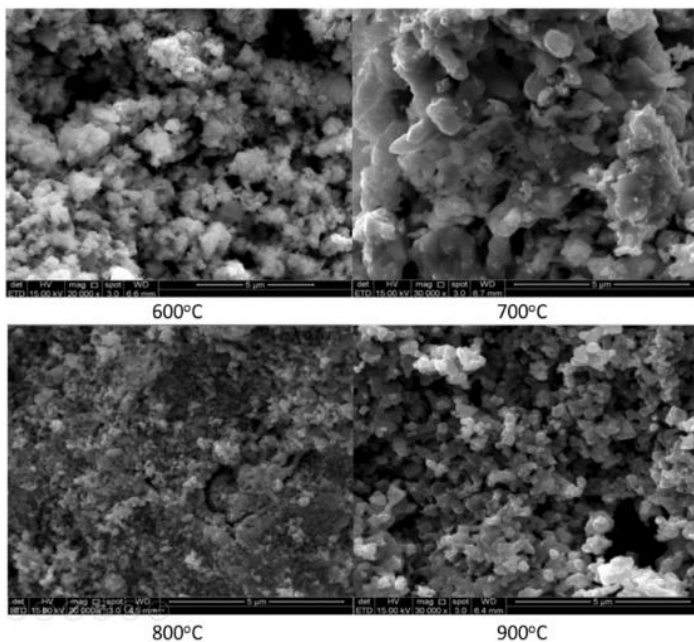

(b)
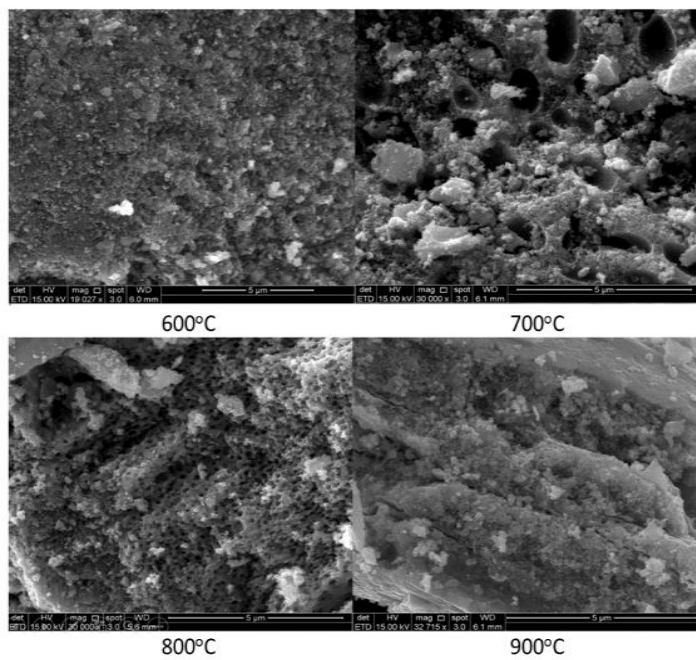

Fig. 4 SEM micrographs of LSCF-CuO powder form by respecting temperature with 5 micrometer magnifications. (a) Solid state route and (b) Sol-gel route. 
Generally, increasing of sintering temperature would result in the increase of grain size and eventually increase the results of the surface area-gas solid interface (triple boundary phase). This will cause the polarization resistance to be increase. However, increased sintering temperature also could lead to electrode particle strongly adhere to the electrolyte surface later on. Therefore, it is important to obtain an electrode particle with fine microstructure and good adhesion to the electrolyte by optimizing the sintering temperature (Fu et al., 2007; Chen et al., 2008; Garcia et al., 2013). Both route showed that the promising results as the structure formed proved having well porous

Further investigation was conducted on the sample in order to identify its particle size. Fig. 5 showed the average particle size for solid state route and sol-gel samples. As the temperature increase, the particle size increase due to the grain growth. Higher sintering temperature produces particle in bulk form while lower sintering temperature produces lower grain size. This happens because as the sintering process continues at higher temperature, the individual powder particles lose their identity completely and grain boundaries move across prior particle boundaries. Sintering also has a predominant effect upon the grain growth. The reduction in the overall surface energy is the true driving force for the grain boundary enlargement and consequently the particle size increases as a function of the temperature. Sintering is the consolidation of a powder by means of prolonged use of elevated temperatures which below the melting point of any major phase of the material. It facilitates the movement of atoms or molecules through the mechanism of mass transport that may be lattice diffusion, surface diffusion or evaporation-condensation and results in the grain growth which has detrimental effect on the properties of the material (Singh et al., 2009).

(a)
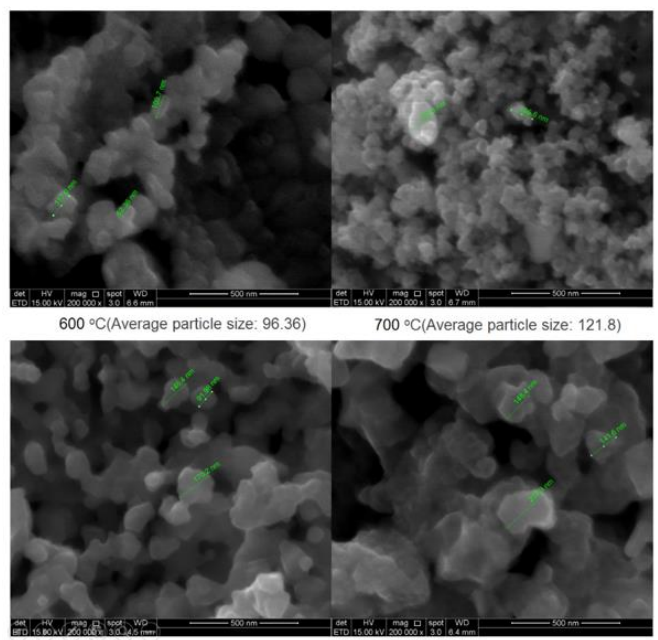

(b)
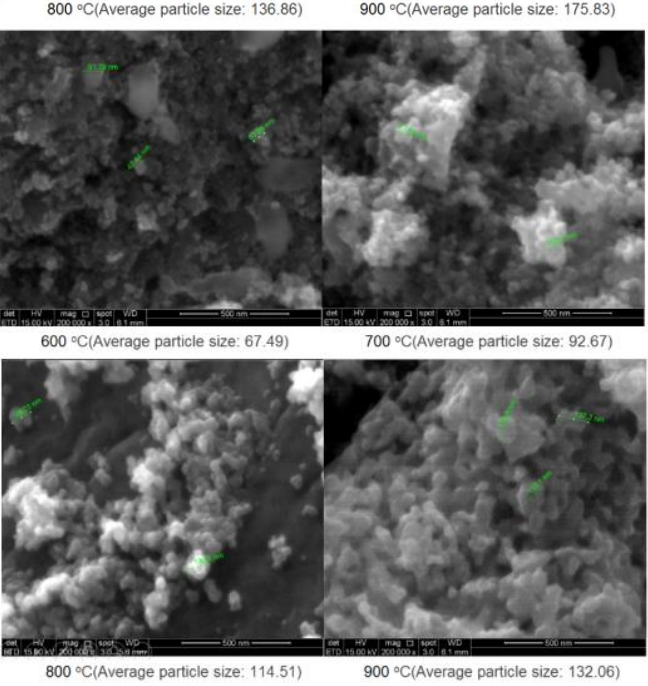

Fig. 5 SEM micrographs of LSCF-CuO powder form by respecting temperature with 500 nanometer magnifications. (a) Solid state route and (b) Sol-gel route.
As a result, the polarization resistance may be increase due to the increasing of particle size. However, there is some aspect more need to be studied in order to identify the LSCF-CuO cathode performance such as the power density of the cathode that would increase the performance of the cathode itself. Based on the Fig. 5, the average particle size for sol-gel is much smaller compare to the solid state route samples. This could be explained since the sol-gel route require much delicate process such polymerization and chelating process help to improve the complete formation of perovskite like LSCF. This is expected to happen due to the sol-gel procedure involves molecular level mixing and results in the homogeneous material formation (Sharma et al., 2014). This may resulted that the particle size of LSCF$\mathrm{CuO}$ via sol-gel route shrink more compare to solid state route due to addition of citric acid and ethylene glycol.

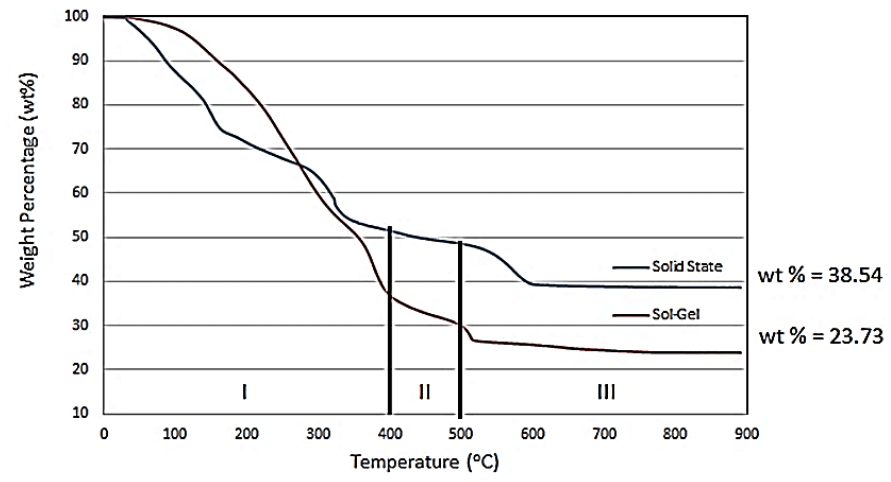

Fig. 6. TGA curve of the as-synthesized LSCF precursor state prepared as solid state and sol-gel method.

The thermogravimetric analysis (TGA) was conducted for each route in order to identify how much weight loss of the sample. This could be signify as the formation of lattice oxygen in a sample. Fig. 6 showed the TGA curves of the weight loss of the precursor sample versus the temperature for solid state route and sol-gel route. The section has been divided into three sections. The first section that happened between $30^{\circ} \mathrm{C}$ to $400^{\circ} \mathrm{C}$ indicates that removal of adsorbed water, decomposition of nitrate and removal of citric acid. This is because water boiling point is at $100^{\circ} \mathrm{C}$ and nitrates usually disappear above $70^{\circ} \mathrm{C}$ and above. As for sol-gel samples, the citric acid disappear at $320^{\circ} \mathrm{C}$. The second phase was a steeper gradient of weight loss. It showed that the metal-citrate decomposition indicating that all the metal salt forming the single phase perovskite. This phase is crucial because the formations of LSCF start to happen and the continuous weight loss represents the LSCF formation keep happening during this range of temperature and formation of oxygen vacancies is happened in this section. The final phase indicate a small weight loss which significant to the formation of oxygen vacancies and the sample start to stabilize to show that the formation of single phase perovskite almost completed This effect also being showed by several researcher researching the effect of TGA toward mixed ionic electronics cathode (MIEC) (Shao et al., 2001; Dongcai et al., 2004; Patra et al., 2011). The results also showed that higher phase pure loses more weight percentage. This could be conclude that phase pure played a role in improving the formation of oxygen vacancies. This could be explained as the formation of oxygen vacancies in increase, the pores will be increase and active surface area also will be increase. Thus, more oxygen reduction reaction (ORR) will be produce resulting electrical conductivity to be increase. As for a comparison, the weight loss of sample via sol-gel route is $76.27 \%$ and weight loss of sample via solid state is $61.46 \%$. This is an initial conclusion that sample via sol-gel route might perform better that solid state route sample due to the amount of lattice oxygen were formed on the sol-gel samples more compare to solid state route. It also align with the SEM result which indicated that the particle size of sol-gel samples route were smaller that solid state due to particle shrinkage of sol-gel better that solid state. 
Table $1 \mathrm{BET}$ analysis for both synthesis route at varied temperature.

\begin{tabular}{ccc}
\hline $\begin{array}{c}\text { Sample } \\
\text { (LSCF-CuO) }\end{array}$ & $\begin{array}{c}\text { Specific surface } \\
\text { area }\left(\mathbf{m}^{2} / \mathbf{g}\right)\end{array}$ & $\begin{array}{c}\text { Total pores } \\
\text { volume }(\%)\end{array}$ \\
\hline Sol-gel $600^{\circ} \mathrm{C}$ & 11.0465 & 38.75 \\
Sol-gel $700^{\circ} \mathrm{C}$ & 8.1583 & 34.53 \\
Sol-gel $800^{\circ} \mathrm{C}$ & 4.1716 & 21.80 \\
Sol-gel $900^{\circ} \mathrm{C}$ & 1.8114 & 4.61 \\
Solid State $600^{\circ} \mathrm{C}$ & 13.3265 & 14.88 \\
Solid State $700^{\circ} \mathrm{C}$ & 4.5542 & 8.99 \\
Solid State $800^{\circ} \mathrm{C}$ & 3.2195 & 9.79 \\
Solid State $900^{\circ} \mathrm{C}$ & 1.4704 & 3.42 \\
\hline
\end{tabular}

The BET analysis was conducted to identify the specific surface area and total pore volume for the LSCF-CuO samples. Table 4.1 shows specific surface area and total pore volumes toward the samples by respective route. The specific surface area for both routes showed the same pattern where the specific surface area decreased with increasing temperature. This effect can be explained as the temperature increases, the particle increased due to the increase in grain size resulted in the specific surface area to be decreased. This result is in line with previous study by previous researchers (Mani et al., 2015; Li et al., 2013; Zawadzki et al., 2010). However, for preparing powder size for slurry type cathode, the temperature higher than $700{ }^{\circ} \mathrm{C}$ is needed. Overall, the specific surface area for sol-gel samples was slightly higher than the solid state samples indicating smaller particles size of the sol-gel samples. This showed that the oxygen reduction reaction process for sol-gel samples was higher than that of solid state samples. The results for total pore volume showed similar pattern as specific surface area whereby the total pores volume decreased with increasing temperature resulting in higher total pores volume of sol-gel samples than the solid state samples. This results supported the analysis from SEM results where the particle size increased as temperature increases causing the grain size to be increasing as well as decreasing specific surface area and total pores volume.

\section{CONCLUSION}

Perovskite type material such as LSCF has a good compatibility with noble metal such as copper oxide $(\mathrm{CuO})$. This was proven by the results of XRD, SEM and EDX. The optimal temperature for LSCF$\mathrm{CuO}$ via solid state is at $800^{\circ} \mathrm{C}$ while via sol-gel is at $600^{\circ} \mathrm{C}$ indicating synthesized LSCF-CuO via sol-gel required much lower calcining temperature as compared with solid state. The EDX showed that no impurities were found for entire samples indicating that both route capable to produce pure samples. The average particle size from SEM for LSCF-CuO via sol-gel route is smaller as compared to solid state route. The SEM analysis also showed that rhombohedral type grain which is good for definition of having a well-structured porosity. The results from SEM also being supported by TGA analysis since the result showed that the weight loss of LSCF-CuO via sol-gel route is much lower compare to solid state route. The results from BET analysis also showed similar aspect as SEM results. As a conclusion from this work, its physicals and chemical analysis showed that synthesizing of LSCF$\mathrm{CuO}$ via sol-gel route able to produce better results compared to the solid state route. This could be an initial conclusion that LSCF-CuO via sol-gel route might perform better than solid state route in term of electrochemical performance.

\section{ACKNOWLEDGEMENT}

Author is gratefully thanked the Ministry of Science, Technology \& Innovation (MOSTI) Malaysia for financially supported this work under Fundamental Research Grant Scheme (FRGS) Malaysia and all the research work conducted in Universiti Sains Malaysia (USM).

\section{REFERENCES}

Chen, J., Liang, F., Liu, L., Jiang, S., Chi, B., Pu, J., \& Li, J. (2008). Nanostructured $(\mathrm{La}, \mathrm{Sr})(\mathrm{Co}, \mathrm{Fe}) \mathrm{O}_{3}+\mathrm{YSZ}$ composite cathodes for intermediate temperature solid oxide fuel cells. Journal of Power Sources, 183(2), 586589.
Dongcai Li, W. L., Zhang, H., Jiang, G., \& Chen, C. (2004). Fabrication, microstructure, mechanical strength and oxygen permeation of $\mathrm{Ba}(\mathrm{Sr}) \mathrm{Zr}(\mathrm{CoFe}) \mathrm{O}_{3}$-particles-dispersed $\quad \mathrm{Ba}_{0.5} \mathrm{Sr}_{0.5} \mathrm{Co}_{0.8} \mathrm{Fe}_{0.2} \mathrm{O}_{3-\delta} \quad$ mixedconducting composites. Materials Letters, 58(10), 1561-1567.

Fleig, J. (2002). On the width of the electrochemically active region in mixed conducting solid oxide fuel cell cathodes. Journal of Power Source, 105(2), 228-238.

Fu, C., Sun, K., Zhang, N., Chen, X., \& Zhou, D. (2007). Electrochemical characteristics of LSCF-SDC composite cathode for intermediate temperature SOFC. Electrochimica Acta, 52(13), 4589-4594.

Garcia, L. M., Macedo, D. A., Souza, G. L., Motta, F. V., Paskocimasa, C. A., \& Nascimento, R. M. (2013). Citrate-hydrothermal synthesis, structure and electrochemical performance of $\mathrm{La}_{0.6} \mathrm{Sr}_{0.4} \mathrm{Co}_{0.2} \mathrm{Fe}_{0.8} \mathrm{O}_{3-\delta}$ cathodes for ITSOFCs. Ceramics International, 39(7), 8385-8392.

Hong, T., Brinkman, K., \& Xia, C. (2016). Copper oxide as a synergistic catalyst for the oxygen reduction reaction on $\mathrm{La}_{0.6} \mathrm{Sr}_{0.4} \mathrm{Co}_{0.2} \mathrm{Fe}_{0.8} \mathrm{O}_{3-\delta}$ perovskite structured electrocatalyst. Journal of Power Sources, 329, 281-289.

Kim, Y., Kim-Lohsoontorn, P., \& Bae, J. (2010). Effect of unsintered gadolinium-doped ceria buffer layer on performance of metal-supported solid oxide fuel cells using unsintered barium strontium cobalt ferrite cathode. Journal of Power Sources, 195(19), 6420.

Li, N., Verma, A., Singh, P., \& Kim, J.-H. (2013). Ceramics International, 39, 529-538.

Lu, L., Shi, Q., Yang, Y., \& Zhang, H. (2012). Electrochemical performance of $(\mathrm{La}, \mathrm{Sr})(\mathrm{Co}, \mathrm{Fe}) \mathrm{O} 3 \mathrm{~d}-(\mathrm{Ce}, \mathrm{Sm}) \mathrm{O} 2 \mathrm{u}-\mathrm{CuO}$ composite cathodes for intermediate temperature solid oxide fuel cells. Material Research Bulletin, 47(1), 10161020 .

Mani, R., Gautam, R. K., Banerjee, S., Srivastava, A. K, Jaswal, A. \& Chattopadhyaya M. C. (2015). A Study on $\mathrm{La}_{0.6} \mathrm{Sr}_{0.4} \mathrm{Co}_{0.3} \mathrm{Fe}_{0.8} \mathrm{O}_{3}$ (LSCF) cathode material prepared by gel combustion method for IT-SOFCs: Spectroscopic, electrochemical and microstructural analysis. Asian Jornal Research Chemistry, 8(6), 389-393.

Minh, N. Q., \& Takahashi, T. (1995). Science and Technology of Ceramic Fuel Cells (1 ${ }^{\text {st }}$ Ed.). Elsevier.

Patra, H., Rout, S. K., Pratihar, S. K. \& Bhattacharya, S. (2011). Thermal, electrical and electrochemical characteristics of $\mathrm{Ba}_{1-\mathrm{x}} \mathrm{Sr}_{\mathrm{x}} \mathrm{Co}_{0.8} \mathrm{Fe}_{0.2} \mathrm{O}_{3-\delta}$ cathode material for intermediate temperature solid oxide fuel cells. International Journal of Hydrogen Energy, 36(18), 11904-11913.

Petitjean, M., Caboche, G., Siebert, E., Dessemond, L.; \& Dufour, L. C. (2005) $\left(\mathrm{La}_{0.8} \mathrm{Sr}_{0.2}\right)\left(\mathrm{Mn}_{1-\mathrm{y}} \mathrm{Fe}_{\mathrm{y}}\right) \mathrm{O}_{3} \pm \delta$ oxides for ITSOFC cathode material?: Electrical and ionic transport properties. Journal European of Ceramics Society, 25(12), 2651-2654.

Ran, S., Winnubst, L., Wiratha, W., \& Blank, D. (2006). Synthesis, sintering and microstructure of $3 \mathrm{Y}-\mathrm{TZP} / \mathrm{CuO}$ nano-powder composites. Journal of the European Ceramic Society, 26(4-5), 391-396.

Reitz, T., Ahmed, S., Krumpelt, M., Kumar, R., \& Kung, H. (2000). Characterization of $\mathrm{CuO} / \mathrm{ZnO}$ under oxidizing conditions for the oxidative methanol reforming reaction. Journal of Molecular Catalysis A: Chemical, 162(1-2), 275-285.

Shao, Z., Xiong, G., Tong, J., Dong, H., \& Yang, W. (2001). Ba effect in doped $\mathrm{Sr}\left(\mathrm{Co}_{0.8} \mathrm{Fe}_{0.2}\right) \mathrm{O}_{3-\delta}$ on the phase structure and oxygen permeation properties of the dense ceramic membranes. Separation and Purification Technology, 25(13), 419-429

Sharma, S., Singh, V., Kotnala, R. K., \& Dwivedi, R. K. (2014). Comparative studies of pure $\mathrm{BiFeO}_{3}$ prepared by sol-gelversus conventional solid-statereaction method. Journal of Material Science, 25(4), 1915-1921.

Simner, S., Anderson, M., Engelhard, M., \& Stevenson, J. (2006). Degradation mechanisms of $\mathrm{La}-\mathrm{Sr}-\mathrm{Co}-\mathrm{Fe}-\mathrm{O}_{3} \mathrm{SOFC}$ cathodes. Electrochemical and SolidState Letters, 9(10), A478-A481.

Singh, P., \& Minh, N. (2004). Solid oxide fuel cells: Technology status. International Journal of Applied Ceramic Technology, 1(1), 5-15.

Singh, R. C., Singh, M. P., Singh, O., \& Chandi, P. S. (2002). Influence of synthesis and calcination temperatures on particle size and ethanol sensing behaviour of chemically synthesized $\mathrm{SnO}_{2}$ nanostructures. Sensors and Actuators B: Chemical, 143(1), 226-232.

Singhal, S. (2000). Advanced in solid oxide fuel cell technology. Solid State Ionics, 135(1-4), 305-313.

Simner, S. P., Bonnett, J. F., Canfield, N. L., Meinhardt, K. D., Shelton, J. P., Sprenkle V. L. \& Stevenson, J. W. (2003). Development of lanthanum ferrite SOFC cathodes. Journal of Power Sources, 113(1), 1-10.

Virkar, A. V.; Chen, J., Tanner, CW. \& Kim, J. W. (2000). The role of electrode microstructure on activation and concentration polarizations in solid oxide fuel cells. Solid State Ionics, 131(1-2), 189-198.

Zawadzki, M., Grabowska, H., \& Trawczyński, J. (2010). Effect of synthesis method of LSCF perovskite on its catalytic properties for phenol methylation. Solid State Ionics, 181(23-24), 1131-1139.

Zhu, X., Ding, D., Li, Y., Lü, Z., Su, W., \& Zhen, L. (2013). Development of $\mathrm{La}_{0.6} \mathrm{Sr}_{0.4} \mathrm{Co}_{0.2} \mathrm{Fe}_{0.8} \mathrm{O}_{3-\delta}$ cathode with an improved stability via $\mathrm{La}_{0.8} \mathrm{Sr}_{0.2} \mathrm{MnO}_{3}$ film impregnation. International Journal of Hydrogen Energy, 38(13), 53755382 . 
Zhao, C. H., Liu, R. Z., Shao, L., Wang, S. R. \& Wen, T. L. 2009. Effects of

$\mathrm{CuO}$ addition to anode on the electrochemical performances of cathode-

supported solid oxide fuel cells. Electrochemistry Communications, 11(12),

2300 . 